\title{
Determination of Attitudes and Awareness Levels of Classroom Teachers for Gifted Students According to Some Demographic Variables ${ }^{1}$
}

\author{
Özlem Katırc1 ${ }^{2}$ \\ Duygu Gür Erdoğan ${ }^{3}$
}

\begin{abstract}
The main purpose of this study is to determine the attitudes of the classroom teachers towards gifted students and their awareness levels towards gifted students' behavioral characteristics according to some demographic variables. In this study conducted for this purpose, screening model, which is one of the quantitative research methods, was used. Study group of the research consists of classroom teachers working in schools in the center and districts of Kocaeli Province in the 2018-2019 academic year. In the study, the "Attitude Scale for Gifted Students" which is studied in terms of its validity and reliability by Erdoğan (2016) and the "Scale for Rating Behavioral Characteristics of Gifted Students" developed by Şahin (2012) were used as data collection tools. According to the findings of the study, while there is no significant difference in classroom teachers' attitudes towards gifted students and, their educational attitudes and awareness towards their behavioral characteristics according to gender and educational status. However, a significant difference was found in favor of those who attended the education in terms of whether they attend any education related to gifted people on "attitude towards support needs" and "attitude towards talent grouping" sub-dimensions.
\end{abstract}

Keywords: Classroom teacher, education of gifted, behavioral characteristics in gifted

\section{INTRODUCTION}

In line with some basic thoughts about the importance of the education of gifted children, studies have started in many countries and innovation process has been initiated in this direction in education systems. For example; a breakthrough in gifted education was made in the USA in 1958 with a special law. In this country, many practises such as expediting, class upgrading, course passing, crediting, early starting to secondary school, high school or university, etc. are implemented (Akarsu, 2001, 27-32). The main strategies used in many educational practises regarding gifted education are called as expediting (with intensive courses), enrichment and grouping. It is planned to develop higher-order thinking skills such as creative, critical and scientific thinking and problem solving with enrichment strategies. In the content of enrichment strategies; topics, activities, performance studies and projects to improve these skills are included. In addition, independent studies of students, making trips to cultural and scientific fields or professional organizations, inviting event-based speakers, learning centers created within the classroom or school's support room, weekend programs, activities implemented under consultancy,

\footnotetext{
${ }^{1}$ This study was issued on the basis of the master's thesis study of the first author, conducted under the supervision of the second author.

2 MA, Sakarya University, Turkey, ozlemk@hotmail.com

${ }^{3}$ Assist, Prof. Dr., Sakarya University, Faculty of Education, Department of Educational Sciences, Turkey, dgur@sakarya.edu.tr
} 
summer programs or summer camps can be given as an example for enriching the students in terms of their content (Davasligil, 2004).

Participation in enriched education programs, especially from a young age, is considered important for the emergence of the potential that gifted individuals have in themselves. In this context, classroom teachers, who provide education and training services to gifted children in primary schools, should have the knowledge and equipment related to these children, direct them to the relevant institutions in line with their educational needs accordingly, and have the professional experience that will enable them to actively participate in the learning environment with their peers in the classroom. Classroom teacher can be defined as the person who transfers the information about the subject areas in the education programs of primary schools to the children, and leads them to make researches, being creative and initiative, helps students to develop positive attitudes towards themselves and the outer world, and provides the development of effective communication skills with others (Tok \& Bozkurt, 2010, 762).

The knowledge levels of the classroom teachers related to gifted children; with the concept knowledge and test knowledge in the relevant field, test practises within the framework of the formation, the objectives and student recruitment conditions of the institutions serving in this field, having acquired skills at the practise level related to the education models applied for gifted children and having scientific knowledge in regard with physical, mental, personality and social characteristics of gifted children may help those teachers to serve the purpose. In this context, it can be said that the knowledge of the teacher in the related topics will help effective and timely guidance of gifted children and having proper education.

\section{METHOD}

\section{Research Model}

In this study, according to some demographic variables, the attitudes of classroom teachers towards gifted students within the classroom and awarenes towards gifted students' behavioral characteristics were tried to be determined. In this study conducted for this purpose, screening model, one of the quantitative research methods, was used.

\section{Study Group}

Study group of the research; in the 2018-2019 academic year, consists of classroom teachers working in schools in the central district and other districts of Kocaeli.

Table 1.

Socio-Demographic and Educational Status of Teachers

\begin{tabular}{llll}
\hline & & $n$ & $\%$ \\
\hline \multirow{3}{*}{ Gender } & Female & 214 & 76.7 \\
\multirow{2}{*}{ Educational Status } & Male & 65 & 23.3 \\
& Bachelor Degree & 237 & 84.9 \\
\hline
\end{tabular}




\begin{tabular}{|c|c|c|c|}
\hline & Masters Degree & 42 & 15.1 \\
\hline Total & & 279 & 100.0 \\
\hline
\end{tabular}

As can be seen from Table 1, 76.7\% $(N=214)$ of the participating individuals are women and $23.3 \%(N=$ 65) are men. $84.9 \%(N=237)$ of the individuals participating in the research have Bachelor Degree degree and $15.1 \%(N=42)$ have Master Degree.

\section{Data Collection and Data Collection Tools}

\section{Attitude Scale for Gifted Students and Their Education}

The scale, developed by Gagné and Nadeau (1991) and originally named "Opinions about the Gifted and Their Education", was developed as 34 items, and in 1991, another item was added and finalized. The validity study of the scale was done by Erdoğan (2016) and the number of items in the scale decreased to 21. The scale consists of six factors. The emerging factors were called Support Need, Exclusion and Isolation, Special Education Need, Social Value, Class Upgrading and Talent Grouping. In the study conducted by Erdoğan (2016), the reliability coefficient of the scale was determined as .72. For this study, the Cronbach Alpha reliability coefficient of the scale's total test score was found as .78.

\section{Behavioral Characteristics of Gifted Students Scale}

The scale was developed by Şahin (2012) to determine the level of knowledge about the characteristics of gifted students who attend classes in the $2 \mathrm{nd}, 3 \mathrm{rd}$, 4th and 5th grades of primary education in the public education schools. The scale was prepared in a 5-point Likert type. Answers to the items in the scale are: Always - 5, often - 4, sometimes - 3, rarely - 2 and never - 1. The "Awareness towards the Behavioral Characteristics of Gifted Students" scale has a 3-factor structure, "Awareness towards the Problem Solving Characteristics", "Awareness towards the Communication and Social Skills Characteristic" and "Awareness towards the General Cognitive Characteristics" and consists of 34 items in total. The highest score that can be obtained from the scale is 170 , the lowest score is 34 , and the average score is 102. Cronbach-Alpha internal consistency coefficient of the scale was calculated as .86, first sub-factor .92 , second sub-factor .82 and third sub-factor .71. For this study, Cronbach Alpha reliability coefficient of the scale's total test score was found was .90 .

\section{Data Analysis}

The research data were analyzed using SPSS package program version 16.0. When the internal consistency coefficients are analyzed at the data analysis stage, it is seen that the scales are sufficiently reliable $(\alpha>.60)$. After analyzing the scores of the scales, whose internal consistency was revealed secondly, the suitability of the variables to normal distribution was tested. When the skewness and kurtosis statistics were examined, it was determined that the values of all variables were in the range of 1 and +1 (Demir et al., 2016: 133) and showed normal distribution accordingly. At this point, it was decided to use parametric analysis techniques to analyze the data. In the research, data were analyzed by using Independent Samples T-Test. In the research, $p=.05$ was accepted for the level of significance.

\section{FINDINGS}


In this section, the findings obtained with the data collection tool are presented. The differentiation status of the teachers who constitute the sample of the study in their attitude scores by gender is shown in Table 2.

Table 2.

Research on Classroom Teachers' Attitudes towards Gifted Students and Their Education According to Gender

\begin{tabular}{|c|c|c|c|c|c|c|c|}
\hline Scale & Gender & $N$ & $\bar{x}$ & $S D$ & $t$ & $D F$ & $p$ \\
\hline \multirow{2}{*}{$\begin{array}{l}\text { Attitude towards Gifted Students and Their } \\
\text { Education }\end{array}$} & Female & 214 & 69.71 & 8.64 & \multirow{2}{*}{-.126} & \multirow{2}{*}{277} & \multirow{2}{*}{.900} \\
\hline & Male & 65 & 69.86 & 7.94 & & & \\
\hline \multirow{2}{*}{ Need of Support } & Female & 214 & 10.59 & 2.64 & \multirow{2}{*}{2.460} & \multirow{2}{*}{277} & \multirow{2}{*}{.015} \\
\hline & Male & 65 & 9.68 & 2.53 & & & \\
\hline \multirow{2}{*}{ Exclusion and Isolation } & Female & 214 & 15.05 & 3.24 & \multirow{2}{*}{.604} & \multirow{2}{*}{277} & \multirow{2}{*}{.546} \\
\hline & Male & 65 & 14.77 & 3.24 & & & \\
\hline \multirow{2}{*}{ Need for Special Education } & Female & 214 & 8.75 & 2.12 & \multirow{2}{*}{-2.050} & \multirow{2}{*}{277} & \multirow{2}{*}{.041} \\
\hline & Male & 65 & 9.34 & 1.63 & & & \\
\hline \multirow[b]{2}{*}{ Social Value } & Female & 214 & 13.44 & 3.14 & \multirow[b]{2}{*}{-.973} & \multirow[b]{2}{*}{277} & \multirow[b]{2}{*}{.331} \\
\hline & Male & 65 & 13.89 & 3.73 & & & \\
\hline \multirow{2}{*}{ Class Upgrading } & Female & 214 & 11.64 & 2.63 & \multirow{2}{*}{-1.653} & \multirow{2}{*}{277} & \multirow{2}{*}{.099} \\
\hline & Male & 65 & 12.25 & 2.45 & & & \\
\hline \multirow[b]{2}{*}{ Talent Grouping } & Female & 214 & 10.39 & 2.43 & \multirow[b]{2}{*}{.464} & \multirow[b]{2}{*}{277} & \multirow[b]{2}{*}{.643} \\
\hline & Male & 65 & 10.23 & 2.23 & & & \\
\hline
\end{tabular}

According to the independent sample t-test results in Table 2, the attitude of classroom teachers towards gifted students and their education $(t(277)=-.126, p>.05)$, attitude towards exclusion and isolation $(t$ $(277)=.604, p>.05)$, attitude towards social values related to gifted students $(t(277)=-.973, p>.05)$, attitude towards class upgrading $(t(277)=-1.653, p>.05)$ and attitude towards the talent grouping $(t$ $(277)=.464, p>.05)$ did not differ significantly by gender, but the attitude level towards the need for support was significantly different in favor of female teachers, $(t(277)=2.460, p<.05)$ while the level of attitude towards the need for special education was male $(t(277)=2.050, p<.05)$. It has been determined that there is a significant difference in favor of teachers.

Table 3.

Research on Awareness Levels of Classroom Teachers towards Behavioral Characteristics of Gifted Students by Gender

\begin{tabular}{lllllllllll}
\hline Scale & Gender & $N$ & $\bar{x}$ & $S D$ & $t$ & $D F$ & $p$ \\
\hline
\end{tabular}




\begin{tabular}{|c|c|c|c|c|c|c|c|}
\hline \multirow{2}{*}{$\begin{array}{l}\text { Awareness towards behavioral characteristics of } \\
\text { gifted students }\end{array}$} & Female & 214 & 130.06 & 15.30 & \multirow{2}{*}{1.321} & \multirow{2}{*}{277} & \multirow{2}{*}{.188} \\
\hline & Male & 65 & 127.20 & 15.19 & & & \\
\hline \multirow{2}{*}{$\begin{array}{l}\text { Awareness towards problem solving } \\
\text { characteristics }\end{array}$} & Female & 214 & 74.94 & 9.12 & \multirow{2}{*}{1.398} & \multirow{2}{*}{277} & \multirow{2}{*}{.163} \\
\hline & Male & 65 & 73.05 & 10.92 & & & \\
\hline \multirow{2}{*}{$\begin{array}{l}\text { Awareness towards communication and social } \\
\text { skills }\end{array}$} & Female & 214 & 34.44 & 6.63 & \multirow{2}{*}{-1.402} & \multirow{2}{*}{277} & \multirow{2}{*}{.162} \\
\hline & Male & 65 & 35.69 & 5.00 & & & \\
\hline \multirow{2}{*}{$\begin{array}{l}\text { Awareness towards general cognitive } \\
\text { characteristics }\end{array}$} & Female & 214 & 20.67 & 4.81 & \multirow{2}{*}{3.135} & \multirow{2}{*}{277} & \multirow{2}{*}{.002} \\
\hline & Male & 65 & 18.46 & 5.52 & & & \\
\hline
\end{tabular}

According to the independent sample t-test results in Table 3, awarenes towards classroom teachers towards behavioral characteristics of gifted students $(t(277)=1.321, p>.05)$, awarenes towards problem solving characteristics $(t(277)=1.398, p>.05)$, awareness towards communication and social skills $(t$ $(277)=-1.402, p>.05)$ does not differ significantly by gender, but awareness towards general cognitive characteristics $(t(277)=3.135, p<.01)$ level was found to differ significantly by gender.

Table 4.

Research on Classroom Teachers' Attitudes towards Gifted Students and Their Education According to Educational Status

\begin{tabular}{|c|c|c|c|c|c|c|c|}
\hline Scale & Educational Status & $N$ & $\bar{x}$ & $S D$ & $t$ & $D F$ & $p$ \\
\hline \multirow{2}{*}{$\begin{array}{l}\text { Attitude towards Gifted Students } \\
\text { and Their Education }\end{array}$} & Bachelor Degree & 237 & 69.49 & 8.21 & \multirow{2}{*}{-1.181} & \multirow{2}{*}{277} & \multirow{2}{*}{.239} \\
\hline & Master Degree & 42 & 71.17 & 9.77 & & & \\
\hline \multirow{2}{*}{ Need of Support } & Bachelor Degree & 237 & 10.31 & 2.64 & \multirow{2}{*}{-1.027} & \multirow{2}{*}{277} & \multirow{2}{*}{.306} \\
\hline & Master Degree & 42 & 10.76 & 2.65 & & & \\
\hline \multirow{2}{*}{ Exclusion and Isolation } & Bachelor Degree & 237 & 14.78 & 3.24 & \multirow{2}{*}{-2.439} & \multirow{2}{*}{277} & \multirow{2}{*}{.015} \\
\hline & Master Degree & 42 & 16.10 & 3.01 & & & \\
\hline \multirow{2}{*}{ Need for Special Education } & Bachelor Degree & 237 & 8.95 & 1.87 & \multirow{2}{*}{1.266} & \multirow{2}{*}{277} & \multirow{2}{*}{.207} \\
\hline & Master Degree & 42 & 8.52 & 2.75 & & & \\
\hline \multirow[b]{2}{*}{ Social Value } & Bachelor Degree & 237 & 13.61 & 3.15 & \multirow[b]{2}{*}{.757} & \multirow[b]{2}{*}{277} & \multirow[b]{2}{*}{.449} \\
\hline & Master Degree & 42 & 13.19 & 4.02 & & & \\
\hline \multirow[b]{2}{*}{ Class Upgrading } & Bachelor Degree & 237 & 11.62 & 2.50 & \multirow{2}{*}{-2.419} & \multirow{2}{*}{277} & \multirow{2}{*}{.016} \\
\hline & Master Degree & 42 & 12.67 & 2.95 & & & \\
\hline \multirow[b]{2}{*}{ Talent Grouping } & Bachelor Degree & 237 & 10.39 & 2.14 & \multirow[b]{2}{*}{.684} & \multirow[b]{2}{*}{277} & \multirow[b]{2}{*}{.495} \\
\hline & Master Degree & 42 & 10.12 & 3.49 & & & \\
\hline
\end{tabular}


According to the independent sample t-test results in Table 4, the attitudes towards the gifted students and their education $(t(277)=-1.181, p>.05)$, attitude towards the need for support $(t(277)=-1.027, p>$ $.05)$ attitude towards the need for special education $(t(277)=1.266, p>.05)$, attitude towards social values related to gifted students $(t(277)=.757, p>.05)$ and attitude towards talent grouping $(t(277)=$ $.684, p>.05)$ levels do not differ significantly according to the educational level, but attitude towards exclusion and isolation $(t(277)=-2.439, p<.05)$, attitude towards class upgrading was determined that the level of $(t(277)=-2.419, p<.05)$ showed a significant difference according to the education level.

\section{Table 5.}

Research on Classroom Teachers 'Awareness Levels of Gifted Students' Behavioral Characteristics According to Educational Status



According to the independent sample t-test results in Table 5, awarenes towards classroom teachers' behavioral characteristics of gifted students $(t(277)=.420, p>.05)$, awarenes towards problem solving characteristics $(t(277)=-.193, p>.05)$, awarenes towards the communication and social skills Characteristic $(t(277)=1.247, p>.05)$ and awarenes towards the general cognitive Characteristics $(t$ (277) $=.087, p>$.05) levels was determined that there was no significant difference according to the education level.

Table 6.

Examining the Attitude Levels of Classroom Teachers towards Gifted Students and Their Education According to the Status of Participation in the Seminar/Training with Gifted Students

\begin{tabular}{llllllll} 
Scale & $\begin{array}{l}\text { Status of Participation in } \\
\text { the Seminar/Training with }\end{array}$ & $N$ & DF & $p$ \\
\hline
\end{tabular}




\begin{tabular}{|c|c|c|c|c|c|c|c|}
\hline & Gifted Students & & & & & & \\
\hline \multirow{2}{*}{$\begin{array}{l}\text { Attitude towards Gifted } \\
\text { Students and Their Education }\end{array}$} & No & 166 & 70.08 & 8.70 & \multirow{2}{*}{.795} & \multirow{2}{*}{277} & \multirow{2}{*}{.427} \\
\hline & Yes & 113 & 69.26 & 8.13 & & & \\
\hline \multirow{2}{*}{ Need of Support } & No & 166 & 10.73 & 2.62 & \multirow{2}{*}{2.782} & \multirow{2}{*}{277} & \multirow{2}{*}{.006} \\
\hline & Yes & 113 & 9.85 & 2.60 & & & \\
\hline \multirow{2}{*}{ Exclusion and Isolation } & No & 166 & 14.69 & 3.35 & \multirow{2}{*}{-1.855} & \multirow{2}{*}{277} & \multirow{2}{*}{.065} \\
\hline & Yes & 113 & 15.42 & 3.03 & & & \\
\hline \multirow[b]{2}{*}{ Need for Special Education } & No & 166 & 8.92 & 1.80 & \multirow[b]{2}{*}{.327} & \multirow[b]{2}{*}{277} & \multirow[b]{2}{*}{.744} \\
\hline & Yes & 113 & 8.84 & 2.33 & & & \\
\hline \multirow{2}{*}{ Social Value } & No & 166 & 13.48 & 3.08 & \multirow{2}{*}{-.387} & \multirow{2}{*}{277} & \multirow{2}{*}{.699} \\
\hline & Yes & 113 & 13.64 & 3.58 & & & \\
\hline \multirow[b]{2}{*}{ Class Upgrading } & No & 166 & 11.83 & 2.47 & \multirow[b]{2}{*}{.389} & \multirow[b]{2}{*}{277} & \multirow[b]{2}{*}{.698} \\
\hline & Yes & 113 & 11.71 & 2.78 & & & \\
\hline \multirow[b]{2}{*}{ Talent Grouping } & No & 166 & 10.61 & 2.25 & \multirow[b]{2}{*}{2.198} & \multirow[b]{2}{*}{277} & \multirow[b]{2}{*}{.029} \\
\hline & Yes & 113 & 9.97 & 2.54 & & & \\
\hline
\end{tabular}

According to the Independent Sample T-Test results in Table 6, attitudes towards gifted students and their education $(t(277)=.795, p>.05)$, attitude towards exclusion and isolation $(t(277)=-1.855, p>.05)$, attitude towards the need for special education $(t(277)=.327, p>.05)$, attitude towards social values related to gifted students $(t(277)=-.387, p>.05)$, the attitude towards the class upgrading $(t(277)=.389$, $p>.05)$ did not differ significantly from the level of participation in the seminar/training related to gifted students, but attitude towards the need for support $(t(277)=2.782, p<.01)$ and attitude towards talent grouping $(t(277)=2.198, p<.05)$ were found to differ significantly compared to the level of participation in the seminar/training related to gifted students.

Table 7.

Research on Classroom Teachers' Awareness Levels Regarding Behavioral Characteristics of Gifted Students According to Their Participation in Seminars/Training with Gifted Students

\begin{tabular}{|c|c|c|c|c|c|c|c|}
\hline Scale & $\begin{array}{l}\text { Status of Participation in } \\
\text { the Seminar/Training } \\
\text { with Gifted Students }\end{array}$ & $N$ & $\bar{x}$ & $S D$ & $t$ & $D F$ & $p$ \\
\hline $\begin{array}{l}\text { Awareness towards behavioral } \\
\text { characteristics of gifted students }\end{array}$ & $\begin{array}{l}\text { No } \\
\text { Yes }\end{array}$ & $\begin{array}{l}166 \\
113\end{array}$ & $\begin{array}{l}130.80 \\
127.33\end{array}$ & $\begin{array}{l}14.83 \\
15.78\end{array}$ & 1.868 & 277 & .063 \\
\hline $\begin{array}{l}\text { Awareness towards problem solving } \\
\text { characteristics }\end{array}$ & $\begin{array}{l}\text { No } \\
\text { Yes }\end{array}$ & $\begin{array}{l}166 \\
113\end{array}$ & $\begin{array}{l}75.33 \\
73.27\end{array}$ & $\begin{array}{l}9.69 \\
9.32\end{array}$ & 1.767 & 277 & .078 \\
\hline
\end{tabular}




\begin{tabular}{llllllll}
$\begin{array}{l}\text { Awareness towards communication } \\
\text { and social skills }\end{array}$ & No & 166 & 34.98 & 6.90 & & & \\
& Yes & 113 & 34.37 & 5.29 & & & \\
Awareness towards general & No & 166 & 20.48 & 5.46 & & & \\
cognitive characteristics & Yes & 113 & 19.68 & 4.39 & & & \\
\hline
\end{tabular}

According to the independent sample t-test results in Table 5, awarenes towards classroom teachers' behavioral characteristics of gifted students $(t(277)=1.868, p>.05)$, awarenes towards problem solving characteristics $(t(277)=1.767, p>.05)$, awarenes towards communication and social skills characteristic $(t(277)=.794, p>.05)$ and awarenes towards general cognitive characteristics $(t(277)=1.299, p>.05)$ levels were determined that there was no significant difference according to the participation in the seminar / education about gifted students.

\section{DISCUSSION}

As a result of the research, although there is no significant difference in the attitudes of classroom teachers towards gifted students and their education by gender, it is determined that there is a significant difference by gender only in the attitude level in terms of support needs and special education needs. While female teachers' attitudes towards the need for support of gifted students were higher, attitudes towards gifted students' needs for special education of male teachers were higher. While the studies conducted by Metin, Şenol and İnce (2017) and also Gencel and Satmaz (2017) determined that the score of pre-service female teachers were higher for "the attitudes towards needs and support of gifted students" were high, in the study conducted by Erdoğan and Aksoy (2019) it is found that male teachers' attitudes towards the class upgrading were higher. In a study conducted by Tortop (2014), it was found that female pre-service teachers have higher attitudes towards gifted students. However, Begin and Gagne (1994), Ekinci (2002), Chipego (2004), Curtis (2005), Lassig (2009), Tortop and Kunt (2013), Güneş (2015), Demirhan, Kaya-Uyanık, Canan-Güngören, and Gür-Erdoğan, (2016), Sözel (2018), and Yildirim and Öz (2018) stated that gender was not effective on teachers' attitudes towards gifted students' education.

As a result of the research, it was determined that the awareness level of classroom teachers towards gifted students' behavioral characteristics did not differ significantly by gender. Similarly, as a result of the study conducted by Şahin (2012) on the effectiveness of the education program for increasing the level of knowledge of gifted students and their characteristics, the level of awarenes towards classroom teachers towards behavioral characteristics of gifted students did not differ significantly by gender.

As a result of the research, although there is no meaningful difference in the attitudes of the classroom teachers towards gifted students and their education according to their educational status, it was found that there was a significant difference only in the classroom teachers who had master's degrees in the sub-dimensions of attitudes towards exclusion and isolation and towards the way of upgrading the class. In addition, it was determined that the level of awarenes of the classroom teachers towards the behavioral characteristics of gifted students did not differ significantly according to their educational status. As a result of the study carried out by Şayir (2015), it was stated that the level of knowledge of 
the classroom teachers about gifted children varied significantly according to their education levels and this difference was in favor of the teachers who had master education.

As a result of the research, it was determined that the awareness level of classroom teachers towards gifted students' behavioral characteristics did not differ significantly by gender. Similarly, as a result of the study conducted by Şahin (2012) on the effectiveness of the education program to increase the level of knowledge of gifted students and their characteristics, it was determined that the awareness level of classroom teachers towards gifted students' behavioral characteristics did not differ significantly by gender.

As a result of the research, although there is no significant difference in the attitudes of the classroom teachers towards gifted students and their education according to their educational background, it was determined that the attitude levels in the sub-dimensions towards exclusion and isolation status and towards the way of passing the class showed a significant difference among graduate teachers. In addition, it was determined that the awareness level of classroom teachers towards the behavioral characteristics of gifted students did not differ significantly according to their educational status. As a result of the study carried out by Şayir (2015), it was stated that the level of knowledge of the classroom teachers about gifted children varied significantly according to their education levels and this difference was in favor of the teachers who had master education.

As a result of the research, although there is no significant difference in the attitudes of the classroom teachers towards gifted students and their education, in terms of their participation in the seminar/training related to gifted students, there was a significant difference only in the level of attitude levels in the need for support and talent grouping according to their participation in the seminar/training. In the study conducted by Gencel and Satmaz (2017), it was determined that there was a significant difference in the need and support sub-dimension of gifted students. In addition, in the study conducted by Yildirim and Öz (2018), it was found that the attitudes of the participants who took courses on special education were significantly different. With the studies carried out by Büyükcan (2008), Şahin (2012), and Alkan (2013), it was determined that the gifted students have increased their competencies regarding gifted students with the trainings given. Similarly, Lassig (2003) determined that the in-service trainings provided in the research positively affected the attitudes and awarenes towards the participants as well as their attitudes. It is the fact that receiving education for gifted individuals positively affects their attitudes towards education. This situation has been supported by the literature. Many studies show that the attitudes of teachers who receive training for these individuals are also positively affected (Plunket, 2000). The more knowledgeable about the gifted teachers, the more positive the attitude is.

As a result of the research, it has been determined that the awareness level of classroom teachers about the behavioral characteristics of gifted students did not show a significant difference compared to the level of participation in seminars/training about gifted students. Similarly, as a result of the study conducted by Şahin (2012), it was determined that the level of awarenes towards the elementary teachers about the behavioral characteristics of gifted students did not show a significant difference compared to the level of participation in seminars/training about gifted students.

Since gifted children are potentially different from other classmates in terms of learning speed, depth and knowledge they have, teachers should also have a number of different characteristics and 
competencies (Dağlığlu, 2010). It is a very important need to know gifted children in our country as well as in the world, to provide them with the educational processes they need, to discover their interests and abilities and to offer them differentiated, enriched and accelerated educational opportunities (Baykoç \& Özdemir, 2016). Considering these aspects, it is recommended to organize the necessary in-service seminars and increase the trainings in order to enhance the attitudes of the classroom teachers towards the education of gifted students and their awareness level towards the behavioral characteristics of gifted students.

\section{REFERENCES}

Akarsu, F. (2001). Üstün yetenekli çocuklar aileleri ve sorunlari, Ankara: Eduser Yayınları.

Alkan, A. (2013). Öğretmenler için "Üstün zekalı/yetenekli öğrencilerin belirlenmesi eğitim yazllımı"nın geliştirilmesi (Yayınlanmamış Doktora Tezi). Gazi Üniversitesi, Eğitim Bilimleri Enstitüsü, Ankara.

Baykoç, N., \& Özdemir, D. (2016). Sınıfımdaki üstün yetenekli çocuk eğitimci eğitiminin öğretmen görüşlerindeki değişikliklere katkısı. HAYEF Journal of Education, 13(1), 1-10.

Begin, J., \& Gagné, F. (1994). Predictors of a general attitude toward gifted education. Journal for the Education of the Gifted, 18(1), 74-86

Büyükcan, Y. (2008). İlköğretim okullarındaki hizmetiçi eğitim seminerlerinin öğretmenlere yararları. (Yayımlanmamış Yüksek Lisans Tezi). Hacattepe Üniversitesi, Sosyal Bilimler Enstitüsü., Ankara.

Chipego, A. (2004). Factors associatedd with the attitudes of elementary level classroom teachers toward gifted education (Unpublished Doctoral Dissertation). Widener Universty, Chester.

Curtis, J. (2005). Preservice teacher attitudesntoward gifted students and gifted education (Unpublished Doctoral Dissertation). Colombia University, USA.

Dağlığlu, H. E. (2010). Üstün yetenekli çocukların eğitiminde öğretmen yeterlilikleri ve özellikleri. Milli Eğitim Dergisi, 40(186), 72-84.

Davaslıgil, Ü. (2004). Erken çocuklukta üstün zekali çocuklara uygulanacak farklilaşmiş eğitim programi. M., R., Şirin, A, Kulaksızoğlu, \& A., E., Bilgili (Eds), I. Türkiye Üstün Yetenekli Çocuklar Kongresi Makaleler Kitabı içinde, (289-300). Çocuk Vakfı Yayınları, Yayın No: 64, İstanbul.

Demir, E., Saatçioğlu, Ö., \& İmrol F. (2016). Uluslararası dergilerde yayımlanan eğitim araştırmalarının normallik varsayımları açısından incelenmesi, Current Research in Education, 2(3),130-148

Demirhan, E., Kaya-Uyanık ,G., Canan-Güngören, Ö., \& Gür-Erdoğan, D., (2016). Sınıf öğretmeni adaylarının üstün yetenekli eğitimine ilişkin tutumları. ERPA, 2016, Bosna.

Ekinci, A. (2002). İlköğretim okullarının üstün yetenekli çocuklarm eğitimine elverişlilik düzeyi ile ilgili öğretmen görüşlerinin değerlendirilmesi (Yayımlanmamış Yüksek Lisans Tezi). Dicle Üniversitesi, Diyarbakır. 
Erdoğan, C., \& Aksoy, Ö. (2019). Ortaokul öğretmenlerinin üstün yetenekli eğitimine ilişkin tutumlari Balikesir örneği. Anadolu Akademi Sosyal Bilimler Dergisi, 1(2),63-80.

Erdoğan, R. (2016). Üstün zekali öğrenciler ve eğitimlerine yönelik tutum ölçeği. (Yayımlanmamış Yüksek Lisans Tezi). Gaziosmanpaşa Üniversitesi, Tokat

Ergun, M., \& Çetin, Ş. (2019). Fen bilimleri öğretmen adaylarinin üstün yeteneklilerin eğitimine ilişkin tutumlarinin incelenmesi. ISAS 2019, Ankara, Türkiye

Gencel, İ. E., \& Satmaz, İ. (2017). Teacher candidates' attitudes towards education of gifted students. Uluslararası Ĕ̆itim Programları ve Öğretim Çalışmaları Dergisi, 7(14), 49-62.

Güneş, A. (2015). Sınıf öğretmenlerinin üstün yetenekliler eğitimine ilişkin tutum ve öz-yeterliliklerinin incelenmesi. Journal of Gifted Education and Creativity, 2(1), 12-16.

Lassig, C. J. (2003). Gifted and talented education reforms: Effects on teachers' attitudes. In B. Barlett, \& F. Bryer, and D. Roebuck (Eds.), Proceeding 1 st Annual International Conference on Cognition, Language and Special education Research: Remaining Practice: Research, 141-152.

Lassig, C. J. (2009). Teachers' attitudes towards the gifted: the importance of professional development and school culture. Australasian Journal of Gifted Education, 18(2), 32-42.

Metin, N., Şenol, F. B., \& İnce, E. (2017). Öğretmen adaylarının yetenekli çocukların eğitimine yönelik tutumlarının belirlenmesi. Journal of Theoretical Educational Science, 10(1), 95-116.

Şahin, F. (2012). Sinı öğretmenlerinin üstün yetenekli öğrenciler ve özellikleri hakkindaki bilgi düzeylerini arttirmaya yönelik eğitim programinin etkililiği. (Yayınlanmamış Doktora Tezi). Ankara Üniversitesi, Ankara

Şayir, T. (2015). Üstün yetenekli çocuklara ilişkin sınf öğretmenlerinin bilgi düzeylerinin incelenmesi. (Yayımlanmamış Yüksek Lisans Tezi). Yıldız Teknik Üniversitesi, İstanbul

Sözel, H. K. (2019). Öğretmenlerin üstün yetenekli bireylerin eğitimlerine yönelik tutumlarının değerlendirilmesi. Anadolu Üniversitesi Ĕ̆itim Fakültesi Dergisi (AUJEF), 3(1), 40-54.

Tok, H., \& Bozkurt, A. (2010). Sınıf Öğretmenlerinin 1. 2. 3. Sınıflar İçin Ayrı ve 4. 5. Sınıflar İçin Ayrı Yetiştirilmeleri Konusunda Sınıf Öğretmenlerinin Görüsşlerinin Değerlendirilmesi. Gaziantep Üniversitesi Sosyal Bilimler Dergisi, 9, 762.

Tortop, H. S., \& Kunt, K. (2013). İlköğretim öğretmenlerinin üstün yeteneklilerin eğitimine ilişkim tutumlarının incelenmesi. International Online Journal of educational Science, 5(2), 441-451.

Tortop, H. S. (2014). Öğretmen adaylarının üstün yetenekli ve çok kültürlü eğitime ilişkin tutumları. Üstün Yetenekliler Ĕ̆itimi Araştırmaları Dergisi, 2(2), 16-26

Plunket, M. (2000). Impacting on teacher attitudes toward gifted students. Australasion Journal of Gifted Education, 9(2), 33-42.

Yildirim, H. İ., \& Öz, A. Ş. (2018). Öğretmen adaylarinin özel yeteneklilerin eğitimine ilişkin tutumlarinin incelenmesi. Milli Ĕ̆itim Dergisi, 47 (ÖZEL SAYI 1), 91-108. 